\title{
Banana Xanthomonas Wilt: Occurrence and Means of Transmission in Kagera, Mwanza and Mara Regions of Tanzania
}

\author{
Ibrahim Hashim ${ }^{1}$, Robert B. Mabagala ${ }^{2}$ \\ ${ }^{1,2}$ Sokoine University of Agriculture (SUA), Department of Crop Science and Production, Morogoro, Tanzania
}

\begin{abstract}
Banana Xanthomonas wilt (BXW) disease is a major constraint of banana production in the Lake zone (Kagera, Mwanza and Mara) regions of Tanzania where banana plays an important role as a staple food and cash crop. Infected plants die and fruits rendered inedible. To assess the current status of BXW disease field surveys were conducted from December, 2011 to January, 2012 in Kagera, Mwanza and Mara regions. Twenty eighty banana samples with BXW disease symptoms were randomly collected from a total of 147 surveyed fields. Farmers' knowledge of BXW disease was assessed using a checklist, discussions and direct field observations. Isolation of bacteria was done on Yeast Peptone Glucose Agar and identification was done based on morphological, biochemical and pathogenicity test. Results indicated that the incidence of BXW disease was highest (56.7\%) at Ihangiro and the lowest (10 \%) at Ruhija and Mulela, in Muleba District; Nakamwa and Busagami, in Ukerewe District. Such results implied that, BXW disease is still a constraint to banana production in the surveyed districts. The results also indicated that BXW pathogen transmission was through infected farming tools (65.4\%) in Muleba District and infected planting materials in Tarime (50.5\%) and Ukerewe (45.8\%) Districts implying that these were the major means by which BXW disease was spread in the study area. About $58.33 \%$ and $41.67 \%$ of the farmers in Ibare and Kishanda villages, respectively, in Muleba District associated pied crow (Corvus albus L.) with the transmission of BXW causing pathogen. Results based on morphological, biochemical and pathogenicity test indicated that, four out of 16 bacteria isolated from infected banana samples were Xanthomonas campestris pv. musacearum (Xcm). Further studies on the relationship between the pied crow and Xcm transmission in Kagera, Mara and Mwanza regions, are recommended.
\end{abstract}

Keywords: Banana, Xanthomonas wilt, incidence, transmission, Lake Zone, Tanzania

\section{Introduction}

Banana Xanthomonas wilt (BXW) disease caused by Xanthomonas campestris pv. musacearum is a major constraint in banana production in the Lake zone (Kagera, Mwanza and Mara) regions of Tanzania where banana plays an important role as a staple food and cash crop [8]. Infected plants die and fruits rendered inedible [15]. Since its first discovery in Muleba district, the disease has spread rapidly to the neighboring districts of Missenyi, Bukoba, Ngara and Biharamulo (Kagera), Tarime (Mara) and Ukerewe (Mwanza) [8], [Mbega, E. personal communication, 2011].

The BXW disease is characterized by a progressive yellowing and wilting of leaves, uneven/premature ripening of fruits with sections showing unique yellowish blotches in the pulp and dark brown placental scars. Symptoms on floral parts include wilting of bracts, shriveling, rotting of the male buds, and yellow brown flower stalks. When pseudostems and rachis are cut, pockets of pale yellow bacterial ooze appear within 5 to $15 \mathrm{~min}$ [16], [14].

The causal agent of banana wilt disease was first described in 1960s in Ethiopia as Xanthomonas musacearum) [20], and later on in the 1970s, it was renamed as Xanthomonas campestris pv. musacearum (Xcm) [18]. The bacterium affects all commonly grown banana cultivars [15]. It attacks the vascular system of banana, causing wilting and death of the plants [5], [10], [21].

A survey conducted in 2011 by Agricultural Research Institute Maruku showed that about 112 ha of bananas have been uprooted due to BXW disease, causing an annual loss of \$ 840000 in Kagera region alone [Mkulila, S. personal communication, 2012]. In the neighboring countries of Kenya, Rwanda and Uganda, disease incidence of 61.9, 75.6 and $80 \%$, respectively, have been reported, causing yield losses of up to $100 \%$ [5], [9]. In Tanzania, little or no information about BXW disease incidence has been recorded. The BXW disease is spread by contaminated tools, sunbirds, insects such as bees and infected planting materials [13]. However, little or no information is available on the contribution of these sources of inocula on the spread of the pathogen in Tanzania particularly in the areas where BXW disease has been reported. Therefore, the objective of this study was to determine the incidence and mode of transmission of banana Xanthomonas wilt disease in Kagera, Mwanza and Mara Regions, in order to provide information for future disease management programs.

\section{Materials and Methods}

\subsection{Field Surveys and Collection of Infected Banana Samples}

Field surveys were conducted in Kagera, Mwanza and Mara regions using Multi-stage Random sampling procedures [4] with modifications. Modifications included conducting surveys only in districts and villages with BXW disease, whereas within the village banana fields with or without BXW diseases were selected for data collection. Three Districts with high disease pressure namely Muleba (Kagera region), Tarime (Mara Region) and Ukerewe (Mwanza Region) were covered. A total of 17 villages and 147 banana fields were surveyed and inspected for the presence of BXW disease. BXW disease symptoms were identified using a 


\section{International Journal of Science and Research (IJSR) \\ ISSN (Online): 2319-7064}

Index Copernicus Value (2013): 6.14 | Impact Factor (2014): 5.611

diagnostic guide by [6]. A total of 28 banana samples with BXW disease symptoms were randomly collected from 17 surveyed villages. In addition, the locations where samples were collected were marked by recording the altitude, latitude and longitude using the Global Positioning System (GPS).

\subsection{Determination of banana Xanthomonas wilt disease incidence}

In each randomly selected banana fields (previously described under section 2.1), 30 banana plants were randomly selected by making two diagonal transect walk as described by [7] with modification, where fields with only few banana mats, infected banana plants were identified and all banana plants or mats near homestead were counted. From randomly selected 30 banana plants, infected plants were identified and counted. The BXW disease incidence was determined by dividing the number of diseased plants over the total number of observed plants in the field times one hundred to get percentage.

\subsection{Means of transmission of banana Xanthomonas wilt disease}

The means of transmission of BXW disease were determined by visual observation using a scale of 1-7 [9]: where $1=$ No symptom, 2 = Wilting symptoms and yellowing of young plants, $3=$ Wilting leaves of flowering plants, $4=$ Dry male buds and no wilting symptoms on plant, $5=$ Wilting leaves on any plant of the mat and dry male bud, $6=$ Heavy wilting, drying of male bud and premature ripening of fruits and $7=$ Infected leaves were yellow/ necrotic and no bunch development/ discoloration. Scores 2, 3 and 7 were associated with transmission by infected tools or infected planting materials and scores 4, 5 and 6 were associated with insect transmission [9].

\subsection{Sample handling and isolation of Xanthomonas campestris pv. musacearum}

A small section of about $2 \mathrm{~cm} \mathrm{x} 4 \mathrm{~cm}$ from Xanthomonas wilt symptomatic leaves, flower stalk, leaf petioles and stems were exercised using disinfected knife and packed with cotton wool placed on silica gel in vials [Mbega, E. personal communication, 2011]. A total of 28 samples were collected, packed on vials and transported to the African Seed Health Centre (AfSHC) Laboratories, Sokoine University of Agriculture, Morogoro for further processing.

\subsection{Isolation of bacteria from infected samples}

Using the semi-selective media Yeast Peptone Glucose Agar (YPGA) (Yeast $5 \mathrm{~g}$; Peptone $5 \mathrm{~g}$; Glucose $4 \mathrm{~g}$ and Agar $12 \mathrm{~g}$ per litre) [11] to isolate bacteria from infected plant samples, small portions of $4 \mathrm{~mm}^{2}$ were removed and placed into four drops of sterile distilled water and teased by sterile forceps. After 15 seconds a loopful of the extract was streaked, onto YPGA [11]. Inoculated plates were incubated at $28^{\circ} \mathrm{C}$ for up to $72 \mathrm{~h}$. Single yellow colonies were purified on Nutrient Agar (,Lab-Lemco ee powder $1.0 \mathrm{~g}$; Yeast extract $2.0 \mathrm{~g}$; Peptone $5.0 \mathrm{~g}$ and Sodium chloride $15.0 \mathrm{~g}$ per litre) (at $28^{\circ} \mathrm{C}$ for $48-72 \mathrm{~h}$ ). The cultures were preserved at $4^{\circ} \mathrm{C}$ until when used for further analysis [1].

\subsection{Identification of bacterial isolates}

Pure bacterial isolates were identified using physiological and biochemical characteristics, including colony morphology on YPGA, Gram reaction, Kovaces oxidase reaction, nitrate reduction and pathogenecity test) [2]

\subsection{Pathogenicity test}

Pathogenicity tests to confirm the identity of the pathogen $(X \mathrm{~cm})$ were done using a susceptible banana cultivar, Pisang Awak recommended for pathogenicity tests [14]. Forty eight-hour-old bacterial isolates grown on Nutrient Agar were suspended in sterile distilled water and adjusted to 0.3 O.D at $460 \mathrm{~nm}$ (10 -10 cfu/ml bacterial cell concentration) using a spectrophotometer (Phillip Sunnes: Model 21907). One $\mathrm{ml}$ of the bacterial suspension was injected onto the young leaf petiole of three months old suckers planted in pots with sun-dried soil, sand and manure mixture in the ratio of $3: 1: 1$ [12]. Five isolates which were most likely members of the genus Xanthomonas were tested for pathogenicity.

The pots were placed in the screen house. Two banana plants were inoculated per $\mathrm{Xcm}$ isolate. Control plants were inoculated with sterile distilled water. Inoculated banana plants were observed for symptom development daily for up to five weeks and the bacteria were re-isolated as described under 3.1.4.2 - 3.1.4.3 sections and tested for pathogenicity based on Koch"s postulates.

\subsection{Data Analysis}

Banana Xanthomonas wilt disease incidence was calculated using Microsoft Excel 2007. Descriptive statistics (frequencies, means and cross tabulation) were used to describe the means of transmission of BXW disease in Kagera, Mara and Mwanza regions. Quantitative data were analyzed by using SPSS software for windows version 16.0.

\section{Results}

\subsection{Banana Xanthomonas wilt disease incidence}

The results show that the highest BXW disease incidence $(56.7 \%$ and $53.3 \%$ ) was found in Ihangiro and Ibare villages, respectively, and the lowest (10\%) BXW disease incidence was found in Ruhija and Mulela villages inMuleba District (Table 1). In Tarime District BXW disease incidence was $16.6 \%$ and in Ukerewe District, the highest BXW disease incidence was found in the Busangu village (40\%) followed by Namilembe (30\%), Gallu (28.9\%) and Bukonyo (16.6\%) villages (Table 1). The lowest BXW disease incidence $(10 \%)$ in the Ukerewe District was observed in Nakamwa and Busagami villages (Table 2). Such results implied that, the BXW disease is a constraint to banana production in the surveyed Districts. Earlier reports by [8] and [Mbega, E. personal communication, 2011] showed that, BXW is a major disease of banana in these 


\section{International Journal of Science and Research (IJSR) \\ ISSN (Online): 2319-7064}

Index Copernicus Value (2013): 6.14 | Impact Factor (2014): 5.611

Districts. Persistency of BXW disease on banana in these Districts may be attributed by improper BXW disease control methods [Mchunguzi, D.H. personal communication, 2012]. Previous reports [10] show that, cultural practices that require intensive use of tools such as regular leaf removal and removal of excess suckers can contribute to increased BXW disease spread. During these cultural practices, bacteria can easily be transmitted by infected farm tools to health plants [17], [10].

Table 1: Banana Xanthomonas wilt disease incidence in banana fields in Muleba, Tarime and Ukerewe Districts in January, 2012

\begin{tabular}{|c|c|c|c|c|c|c|c|c|c|}
\hline S/N & District & Village & $\begin{array}{c}\text { Longitude } \\
\left({ }^{(}\right)\end{array}$ & Latitude $\left(^{0}\right)$ & $\begin{array}{c}\text { Altitude } \\
(\text { m.a.s.l) }\end{array}$ & $\begin{array}{c}\text { Size } \\
(\text { acres })\end{array}$ & $\begin{array}{c}\text { Sample Plants } \\
(\text { mats })\end{array}$ & $\begin{array}{c}\text { No. of infected } \\
\text { plants (mats) }\end{array}$ & $\begin{array}{c}\text { BXW disease } \\
\text { incidence (\%) }\end{array}$ \\
\hline 1 & Muleba & Ibare & 31.6151 & 1.7487 & 1520 & 2.0 & 30 & 16 & $\mathbf{5 3 . 3}$ \\
\hline 2 & Muleba & Nshambya & 31.6104 & 1.7426 & 1490 & 1.5 & 30 & 10 & $\mathbf{3 3 . 3}$ \\
\hline 3 & Muleba & Rubao & 31.647 & 1.7186 & 1489 & 2.0 & 30 & 4 & $\mathbf{1 3 . 0}$ \\
\hline 4 & Muleba & Ruhija & 31.6194 & 1.7022 & 1469 & 1.2 & 30 & 3 & $\mathbf{1 0 . 0}$ \\
\hline 5 & Muleba & Rubya & 31.6159 & 1.7502 & 1514 & 1.4 & 30 & 13 & $\mathbf{4 3 . 3}$ \\
\hline 6 & Muleba & Ihangiro & 31.5902 & 1.8069 & 1529 & 1.5 & 30 & 17 & $\mathbf{5 6 . 7}$ \\
\hline 7 & Muleba & Kishanda & 31.5886 & 1.7173 & 1527 & 2.0 & 30 & 12 & $\mathbf{4 0 . 0}$ \\
\hline 8 & Muleba & Ihunga & 31.5631 & 1.7272 & 1529 & 1.6 & 30 & 11 & $\mathbf{3 6 . 6}$ \\
\hline 9 & Muleba & Mulela & 31.5478 & 1.7678 & 1535 & 2.0 & 30 & 3 & $\mathbf{1 0 . 0}$ \\
\hline 10 & Muleba & Rwagati & 31.5543 & 1.7574 & 1506 & 1.4 & 30 & 14 & $\mathbf{4 6 . 6}$ \\
\hline 11 & Tarime & Mogabiri & 31.4178 & 1.3722 & 1658 & 1.6 & 30 & 8 & $\mathbf{2 6 . 6}$ \\
\hline 12 & Ukerewe & Bukonyo & 31.9251 & 1.9621 & 1174 & 0.3 & 12 & 2 & $\mathbf{1 6 . 6}$ \\
\hline 13 & Ukerewe & Busangu & 31.8894 & 1.9628 & 1174 & 0.7 & 30 & 12 & $\mathbf{4 0 . 0}$ \\
\hline 14 & Ukerewe & Nakamwa & 31.9371 & 1.9383 & 1193 & 0.3 & 20 & 2 & $\mathbf{1 0 . 0}$ \\
\hline 15 & Ukerewe & Busagami & 31.9471 & 1.9737 & 1186 & 0.3 & 10 & 1 & $\mathbf{1 0 . 0}$ \\
\hline 16 & Ukerewe & Namilembe & 31.9371 & 1.9718 & 1188 & 0.3 & 10 & 3 & $\mathbf{3 0 . 0}$ \\
\hline 17 & Ukerewe & Gallu & 31.8839 & 1.9303 & 1160 & 0.7 & 18 & 5 & $\mathbf{2 8 . 9}$ \\
\hline
\end{tabular}

m.a.s.l = metres above sea level, BXW = Banana Xanthomonas Wilt, ${ }^{*} \mathrm{BXW}$ disease incidence $=$ number of infected plants over total observed plants in the field times one hundred

\subsection{Means of Transmission of Banana Xanthomonas Wilt Disease}

\subsubsection{Transmission by infected tools}

Using 1-7 scale [9] results of the current study show that $23.5 \%, 65.4 \%$ and $29.2 \%$ of banana fields surveyed in Muleba, Tarime and Ukerewe districts, respectively, had typical BXW disease symptoms with scores of 2 and 3 indicating transmission by infected tools (Table 2). Such results implied that, infected farming tools have contributed to BXW disease transmission in the surveyed districts. These results comply with earlier reports by [1] who indicated that infected farm tools can contribute to high disease incidence of up to $90 \%$.

\subsubsection{Transmission by insects}

Results indicated that $8.2 \%$ of banana fields visited in Muleba District had BXW disease symptoms with a mean BXW disease score of 6 , indicating transmission by insect (Table 2). Such low insect transmission may be due to a traditional practice of removing male buds which usually attract insects. Flying insects such as bees feeding on male inflorescences can move with BXW disease causing pathogen from infected male bud to the health inflorescences [13]. Farmers in Muleba District believe that the removal of male buds increases vigour on banana bunches [Mchunguzi, D.H. personal communication, 2012]. Where male buds have not been removed, the spread of $X \mathrm{~cm}$ by insect increases [17].

\subsubsection{Transmission by Planting Materials}

Using the same scale as in section 3.2.1 above, results showed that $50.5 \%, 45.8 \%$ and $15.4 \%$ of the banana fields surveyed in Muleba, Ukerewe and Tarime districts, respectively, showed wilting symptoms with a mean BXW disease score of 2 (Table 2). During the survey field observations showed that recently planted banana plants had BXW disease symptoms (Figure 1).

This implied that, $X \mathrm{~cm}$ was probably transmitted by infected planting materials. Field observations indicated that, farmers use suckers harvested from their old fields or from neighbours for planting. If such planting materials are infected by $X \mathrm{~cm}$ the pathogen can spread across fields and regions [7].

Table 2: Symptoms of banana Xanthomonas wilt disease observed in Muleba, Tarime and Ukerewe Districts in January, 2012

\begin{tabular}{|c|c|c|c|c|}
\hline \multirow[t]{2}{*}{ Types of symptoms observed } & \multicolumn{3}{|c|}{ Fields visited } & \\
\hline & Muleba & Tarime & Ukerewe & $\overline{\mathrm{x}}$ \\
\hline No symptoms & 16.5 & 19.2 & 25.0 & 20.2 \\
\hline $\begin{array}{c}\text { Wilting symptoms and yellowing } \\
\text { of young plants }\end{array}$ & 23.5 & 65.4 & 29.2 & 39.4 \\
\hline Wilting leaves of flowering plants & 1.0 & 0.0 & 0.0 & 0.3 \\
\hline $\begin{array}{c}\text { Wilting symptoms and yellowing } \\
\text { on young plants } \\
\text { and wilting leaves of flowering } \\
\text { plants }\end{array}$ & 50.5 & 15.4 & 45.8 & 37.2 \\
\hline $\begin{array}{c}\text { Heavy wilting, dry male bud and } \\
\text { premature ripening of fruits }\end{array}$ & 8.2 & 0.0 & 0.0 & 2.7 \\
\hline
\end{tabular}

$\overline{\mathrm{X}}=$ Mean

The results also showed that, $84.5 \%$ and $50 \%$ of farmers visited in Muleba and Tarime district, respectively, obtained banana suckers from their own fields (Table 3). In the Ukerewe District, $50 \%$ of the farmers visited obtained 


\section{International Journal of Science and Research (IJSR) \\ ISSN (Online): 2319-7064 \\ Index Copernicus Value (2013): 6.14 | Impact Factor (2014): 5.611}

banana suckers either from their own fields or from their neighbours ${ }^{\text {ee }}$ fields (Table 3). Such results indicated that, farmers in Muleba, Tarime and Ukerewe Districts use banana planting material from local sources. Such a situation can continue to transmit $\mathrm{Xcm}$ in uninfected banana suckers.
Infected planting material has been reported to be among the most important means of spreading systemic bacterial diseases including $\mathrm{Xcm}$ causal agent of BXW [3].

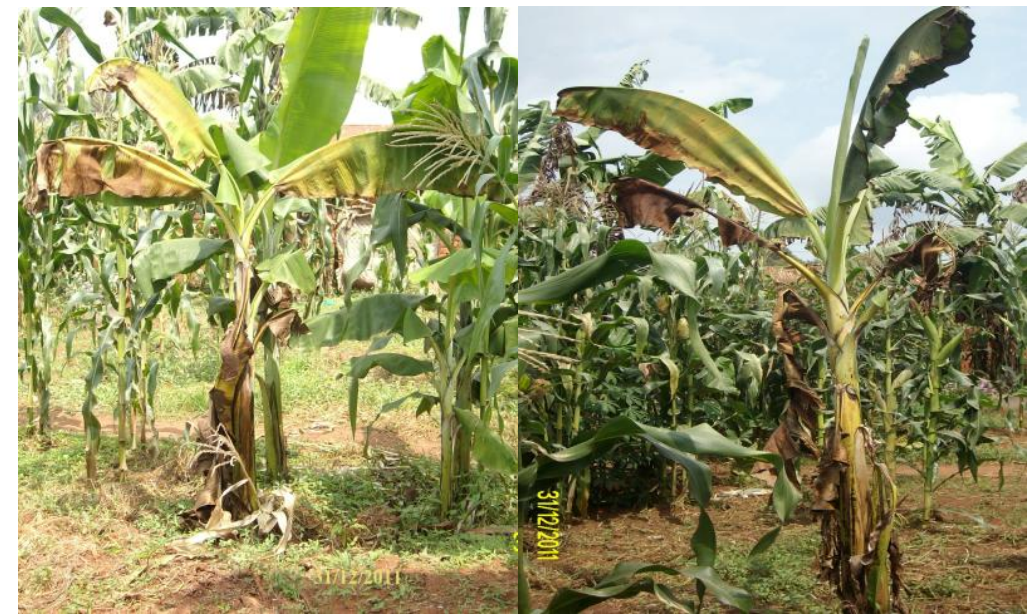

Figure 1: Recent established banana plants showing Xanthomonas wilt disease symptoms indicating that the pathogen was transmitted by infected suckers.

Table 3: Sources of banana planting materials in Muleba, Tarime and Ukerewe Districts in January, 2012

\begin{tabular}{|c|c|c|c|c|}
\hline \multirow{2}{*}{$\begin{array}{c}\text { Source of planting materials } \\
\text { (suckers) }\end{array}$} & \multicolumn{3}{|c|}{$\begin{array}{c}\text { Percentage of farmers } \\
\text { reported }\end{array}$} & \\
\cline { 2 - 5 } & Muleba & Tarime & Ukerewe & $\overline{\mathrm{X}}$ \\
\hline Own & 84.5 & 50.0 & 25.0 & 53.2 \\
\hline Neighbours/friends only & 9.3 & 15.4 & 25.0 & 16.6 \\
\hline $\begin{array}{c}\text { Own and Neighbours/ } \\
\text { friends }\end{array}$ & 6.2 & 34.6 & 50.0 & 30.3 \\
\hline
\end{tabular}

$\overline{\mathrm{X}}=$ Mean

\subsubsection{Transmission by pied crow}

Survey results of this study revealed that $58.33 \%$ and 41.67 $\%$ of farmers ${ }^{e e}$ fields infected with BXW disease at Ibare and Kishanda villages, respectively, in Muleba District were associated with pied crow (Corvus albus L.) (Plate 3a) associated with the increase in BXW disease incidence in their fields (Table 4). During field surveys, the pied crow was found resting on banana leaves (Figure 2a). Injuries on banana leaves caused by frequent visit by the pied crow on healthy and infected banana leaves might have provided an entry point for $\mathrm{Xcm}$ (Figure $2 \mathrm{~b}$ and $2 \mathrm{c}$ ) carried by the bird 's feet and the beak. In Ibare and Kishanda, the birds were often found near rubbish, slaughter houses, markets and farm lands feeding on rubbish, debris, and household leftovers. Small birds feeding on nectar on banana flowers are known to transmit Xcm [17], [13], [1]. No solid evidence on the role of pied crow in transmitting $X \mathrm{~cm}$ but this was speculations only. There is a need to investigate the role of these birds in transmission of $\mathrm{Xcm}$ in banana.

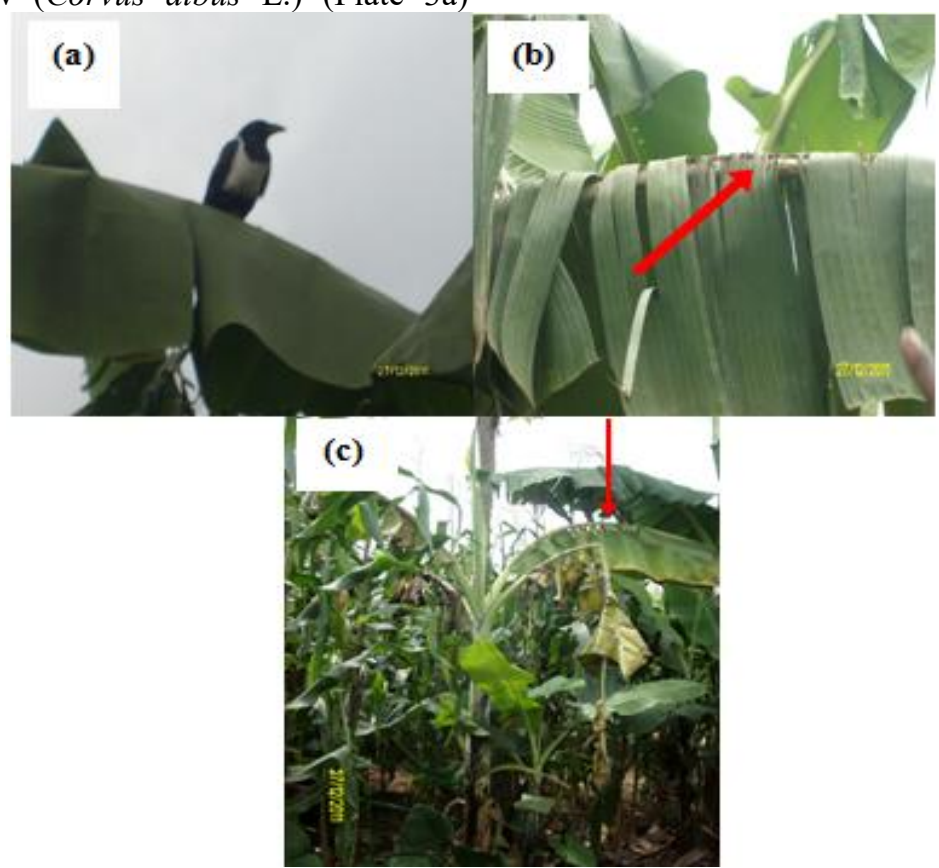

Figure 2: (a): Pied crow resting on banana leaf, (b): red arrow shows the damage caused by the same bird on banana leaf and (c): banana plant wilting due to infection by banana wilt causing xanthomonads. 


\section{International Journal of Science and Research (IJSR) \\ ISSN (Online): 2319-7064}

Index Copernicus Value (2013): 6.14 | Impact Factor (2014): 5.611

Table 4: Villages and banana fields visited by pied crow in Muleba District

\begin{tabular}{|c|c|c|c|}
\hline Village & $\begin{array}{c}\text { No. of fields } \\
\text { affected by pied } \\
\text { crow / total }\end{array}$ & $\begin{array}{c}\text { Fields affected by } \\
\text { pied crow (\%) }\end{array}$ & $\begin{array}{c}\text { BXW disease } \\
\text { Incidence (\%) }\end{array}$ \\
\hline Ibare & $7 / 12$ & 58.33 & 42.20 \\
\hline Kishanda & $5 / 12$ & 41.67 & 39.70 \\
\hline
\end{tabular}

BXW = Banana Xanthomonas Wilt

\subsection{Biochemical characteristics of the bacterial isolate}

Results of biochemical test of the bacteria isolated from banana samples showed that 11 out of the 16 isolates were Gram-negative and five isolates were Gram-positive (Table $5)$. Seven out of the 16 isolates recovered were negative for nitrate reduction and nine isolates were positive for nitrate reduction. Oxidase test was negative for 13 of the 16 isolates and variable for three isolates (Table 5). Based on these results, presumptive identification indicates that, five out of sixteen bacterial isolates were most likely members from the genus Xanthomonas [19].These five isolates were selected for further testing to confirm their identity. Gram- positive, oxidase positive and yellow dry isolates were discarded.

\subsection{Pathogenicity test}

Pathogenicity tests done on three months old potted banana plants indicated that the leaves inoculated with isolate S3 developed water soaking brown necrosis symptoms at the leaf apex within 9 days followed by yellowing of the veins. Plants inoculated with bacterial isolates S0, S1 and S4 showed yellowing around the inoculated area of the leaves within five weeks. Such symptoms were similar to those observed under field conditions. Among the five bacterial isolates; isolate $\mathrm{S} 3$ induced severe $\mathrm{BXW}$ disease symptoms with water soaking, brown necrosis and yellowing earlier than the other isolates. Necrotic symptoms were not observed on the control suckers inoculated with sterile distilled water. The results from the re-isolated bacteria from banana plants inoculated with isolates S0, S1, S3 and S4 showed that the bacteria produced colonies with light to deep yellow color and they were Gram-negative, Oxidase negative. Such results confirmed Koch"s postulates and implied that, these isolates were $\mathrm{Xcm}$ and indeed pathogenic on banana.

Table 5: Biochemical test (Gram reaction, nitrate reduction and oxidase test) and growth characteristic of the bacterial isolates on Yeast Peptone Glucose Agar medium

\begin{tabular}{|c|c|c|c|c|c|c|}
\hline Isolates & Location & $\begin{array}{c}\text { Part } \\
\text { collected }\end{array}$ & Growth on YPGA medium & $\begin{array}{c}3 \% \mathrm{KOH} \\
\text { test }\end{array}$ & $\begin{array}{c}\text { Nitrate } \\
\text { Reduction }\end{array}$ & Oxidase test \\
\hline S5 & Muleba & Stem & Yellow dry colonies & - & + & - \\
\hline S0 & Muleba & Leaf & Light, deep yellow convex colonies & - & - & - \\
\hline S8 & Muleba & Fruit & Yellow dry colonies & + & + & - \\
\hline S1 & Muleba & Leaf & Light, deep yellow convex colonies & - & - & - \\
\hline S6 & Muleba & bunch stalk & Yellow dry colonies & - & + & $+/-$ \\
\hline S10 & Muleba & Fruit & Yellow dry colonies & - & - & - \\
\hline S7 & Tarime & bunch stalk & Yellow dry colonies & + & + & - \\
\hline S16 & Tarime & leaf petiole & Yellow dry colonies & - & + & $+/-$ \\
\hline S2 & Tarime & Leaf & Light, deep yellow convex colonies & - & - & - \\
\hline S11 & Tarime & leaf petiole & Yellow dry colonies & + & + & - \\
\hline S9 & Tarime & Stem & Yellow dry colonies & - & + & - \\
\hline S3 & Tarime & Leaf & Light, deep yellow convex colonies & - & - & - \\
\hline S15 & Tarime & Stem & Yellow dry colonies & & - & $+/-$ \\
\hline S12 & Ukerewe & leaf petiole & Yellow dry colonies & + & + & - \\
\hline S14 & Ukerewe & Fruit & Yellow dry colonies & + & + & - \\
\hline S4 & Ukerewe & Leaf & Light, deep yellow convex colonies & - & - & - \\
\hline
\end{tabular}

$(+/-)=$ Variable, $(-)=$ Negative and $(+)=$ Positive

\section{Conclusion}

In this study BXW disease incidence varied across and within the surveyed areas. The highest BXW disease incidence $(56.7 \%)$ was observed at Ihangiro in Muleba District, Kagera region and the lowest BXW disease incidence $(10 \%)$ was observed at Ruhija and Mulela in Muleba District, Nakamwa and Busagami in Ukerewe District. This implied that BXW disease is a major constraint to banana production in these Districts.

This study has also shown that the major means of BXW disease transmission were infected farming tools $(65.4 \%)$ in Muleba, infected planting materials $(50.5 \%)$ in Tarime and $(45.8 \%)$ in Ukerewe Districts indicating that these were the major means by which $X \mathrm{~cm}$ spread in these Districts. Therefore, training of farmers through seminars on BXW disease transmission methods and management, especially the use of disease free planting materials and proper disinfection of working tools is highly required.

In Kishanda and Ibare villages, Muleba District, farmers associated the pied crow (Covus albus) with BXW disease transmission. Such results indicate that the pied crow may be a potential vector for long distance transmission of $\mathrm{Xcm}$. Currently there is no strong evidence which confirmed in this study that pied crow can transmit $\mathrm{Xcm}$. Therefore, further investigations on the effect of pied crow in transmission of $X \mathrm{~cm}$ in banana are highly required to confirm the current farmers ${ }^{c e}$ allegations on the involvement of the pied crow in transmitting $\mathrm{Xcm}$. 


\section{International Journal of Science and Research (IJSR) \\ ISSN (Online): 2319-7064}

Index Copernicus Value (2013): 6.14 | Impact Factor (2014): 5.611

\section{References}

[1] T. Addis, L. Turyagyenda, T. Alemu, E. Karamura, G. Blomme, , Garden tools transmission of Xanthomonas campestris pv. musacearum on banana ${ }^{\text {eee }}$ In Proceedings of International Conference on Banana and Plantain in Africa, pp. $367-372,2010$.

[2] V. Aritua, N. Parkinson, R. Thwaites, J Heeney, D. Jones W. Tushemereirwe, J. Crozier, R. Reeder, D. Stead, J. Smith, "Characterization of the Xanthomonas sp. causing wilt of ensete and banana and its proposed reclassification as a strain of $X$. visicola" Journal of Plant Pathology, LVII : pp 170 - 177, 2008.

[3] C. Hayward, "Fruit rots of banana caused by Ralstonia solanacearum race 2: questions of nomenclature, transmission and control". InfoMusa XV (2): pp 7 - 10, 2006.

[4] G. Kagezi, A. Kangire, W. Tushemereirwe, F. Bagamba, E. Kikulwe, J. Muhangi, C. Gold, P. Ragama, "Banana Bacterial Wilt incidence in Uganda" African Crop Science Journal XIV (2), pp 83 - 91, 2006.

[5] E. Karamura, M. Osiru, G. Blomme, C. Lusty, P. Claudine, "Containing banana Xanthomonas wilteee In Proceedings of the Workshop, Kampala, Uganda, pp. 4 $-9,2005$.

[6] E. Karamura, F. Turyagyenda, W. Tinzaara, G. Blomme, F. Ssekiwoko, S. Eden-Green, A. Molina, R. Markham, "Xanthomonas wilt of Bananas in East and Central Africa: Diagnostic and management guide". Biodiversity International, Kampala, 2008.

[7] J. Mbaka, V. Nakato, J. Auma, B. Odero, "Status of banana Xanthomonas wilt in Western Kenya and factors enhancing its spread" Journal of African Crop Science IX, pp $673-676,2009$.

[8] S. Mgenzi, S. Eden-Green, J. Peacock, "Overview of banana Xanthomonas wilt in Tanzania" In Proceedings of the $4^{\text {th }}$ International Bacterial wilt symposium, Central Science Laboratory, pp. 107 - 110, 2006.

[9] J. Muhinyuza, S. Gaidasha, L. Dusengemungu, J. Ninyonzima, R. Reeder, "Spread into Rwanda of the devastating banana Xanthomonas wilt disease" In National Conference on Agricultural Research Output Kigali, Rwanda, pp 203, 2007.

[10] J. Mwebaze, G. Tusiime, W. Tushemereirwe, J. Kubiriba, "The survival of Xanthomonas campestris pv. musacearum in soil and plant debris" Journal of African Crop Science XIV (2), pp 121 - 127, 2006a.

[11] J. Mwebaze, G. Tusiime, W. Tushemereirwe, M. Maina, M. "Development of a semi selective medium for Xanthomonas campestris pv. Musacearum eee, Journal of African Crop Science XIV (2), pp 129 - 135, 2006 b.

[12] J. Quimio, "Ensete team support project" Annual Report of the Plant Pathologist, Awasa Research Center, Awasa, Addis Ababa, Ethiopia, 1992.

[13] W. Tinzaara, C. Gold, W. Tushemereirwe, R. Bandyopadhyay, S. Eden- Green, "The possible role of insects in the transmission of banana Xanthomonas wilt" In Proceedings of the $4^{\text {th }}$ International Bacterial wilt Symposium, Central Science Laboratory, York, England, pp. $60-65,2006$.

[14]L. Tripathi, J. Tripathi, "Relative susceptibility of banana cultivars to Xanthomonas campestris pv.
Musacearum", African Journal of Biotechnology, VIII (20), pp 5343-5350, 2009.

[15] W. Tushemereirwe, A. Kangire, J. Smith, M. Nakyanzi, R. Karyeija, D. Kataama, C. Musiitwa, "An outbreak of banana bacterial wilt in Mukono and Kayunga Districts: A new and devastating disease. The first updated disease report, Info Musa, pp 4-8, 2002.

[16] W. Tushemereirwe, A. Kangire, J. Smith, F. Ssekiwoko, M. Nakyanzi, D. Kataama, C. Musiitwa, R. Karyaija, "An outbreak of bacterial wilt on banana in Uganda" Info Musa XIII, pp 6-8, 2003.

[17] W.Tushemereirwe, "The overview of Banana Bacterial Wilt disease in Uganda" In Proceeding of Banana Xanthomonas wilt, Regional Preparedness and Strategy Development Workshop, Kampala, Uganda”, pp. 50 58, 2005.

[18] J. Young, D. Dye, J. Bradbury, C. Panagopoulos, C. Robbs, "A proposed nomenclature and classification for plant pathogenic bacteria" New Zealand Journal of Agricultural Research, XXI, pp 153 - 177, 1978.

[19] Yirgou, D. and Bradbury, J. F. (1968). "Bacterial wilt of Ensete (Ensete ventricosum) incited by Xanthomonas pv. Musacearum", Phytopathology, LVIII,pp 11-121, 1968.

[20] Y. Dagnachew, J. Bradbury "Bacterial Wilt of Enset (Enset ventricosum) incited by Xanthomonas campestris sp". Phytopathology LV pp 111-112, 1968.

[21] M. Biruma, M. Pillay, L. Tripathi, G. Blomme, S. Abele, M. Mwangi, R. Bandyopadhyay, P. Muchunguzi, S. Kassim, M. Nyine, L. Turyagyenda, L. S. EdenGreen, "Banana Xanthomonas wilt: A review of the disease, management strategies and future research directions" as shown in the African Journal of Biotechnology, VI (6), pp 953 - 962, 2007.

\section{Author Profile}

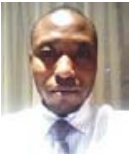

Ibrahim Hashim received the B.Sc. and M.Sc degrees in Agriculture from Sokoine University of Agriculture Tanzania in 2008 and 2013, respectively. From 2009 to - date he is working with the Ministry of Agriculture Food and Cooperatives, Tanzania as an Agricultural Research Officer. He has participated in several extension activities to help farmers and local government agriculture extension staffs to manage insect pests and diseases. He also shared his research information with the local farmers and other researchers. Ibrahim is currently planning to conduct $\mathrm{PhD}$ studies in Agricultural Sciences. His interest is on „Species composition, seasonal abundance and distribution ${ }^{\text {ee }}$ 